\title{
A compreensão e denúncia das violências raciais como genocídio da população negra*
}

\author{
The understanding and denunciation of racial violence as \\ genocide of the black population
}

La comprensión y denuncia de las violencias raciales
como genocidio de la población negra

Recebido em 23-03-2019

Modificado em 27-08-2019

Aceito para publicação em 18-09-2019

\section{dol \\ https://doi.org/10.47456/simbitica.v7i3.33706}

\section{Matheus Silva Freitas}

ORCID: 0000-0001-6245-9085

Mestrando em Educação na Universidade Federal de Minas Gerais (UFMG). Graduado em Ciências Sociais pela Universidade Federal de Viçosa (UFV). Integrante do Núcleo de Estudos Afro-Brasileiros (NEAB Viçosa) e do Grupo de Estudos e Pesquisas em Educação, Gênero e Raça (EDUCAGERA). E-mail: freitassmat@ gmail.com

\section{Resumo}

Este artigo tece uma reflexão sobre a compreensão das relações raciais no Brasil e as violências imbricadas nesse processo enquanto um genocídio da população negra. Para tanto, é feita uma leitura de lutas antirracistas, empreendidas pelos movimentos sociais negros, que denunciam a existência de tal extermínio. Focaliza-se, em especial, o livro "O genocídio do negro brasileiro: o processo de um racismo mascarado" escrito por Abdias Nascimento e três movimentos sociais que atuam especificamente contra o genocídio da juventude negra. A trama costurada ao longo do texto permite apreender que a compreensão das violências contra a população negra enquanto um genocídio têm sido uma estratégia política dos movimentos negros, com a intenção de provocar incômodo com a realidade injusta.

Palavras-chave: Genocídio; violência racial; movimentos negros; genocídio da população negra.

\footnotetext{
* Agradeço à Beatriz Gomes Cornélio pela leitura e comentários assim como aos/as pareceristas anônimos/as que fizeram importantes sugestões. Entretanto, assumo total responsabilidade pela autoria das ideias aqui desenvolvidas. 


\section{Introdução}

As palavras, termos e conceitos tem significados e consequências políticas. Neste artigo, procuramos discutir acerca da definição e compreensão das relações raciais no Brasil e as violências imbricadas neste processo enquanto um genocídio da população negra. Para tanto, fazemos uma análise de lutas antirracistas, empreendidas pelos movimentos sociais negros, que denunciam a existência de tal extermínio. Focalizamos, em especial, o livro "O genocídio do negro brasileiro: o processo de um racismo mascarado"1 escrito por Abdias Nascimento e os movimentos "Reaja, ou será Morto! Reaja, ou será Morta!”, "Mães de Maio” e "Nós temos um sonho" que atuam especificamente contra o genocídio da juventude negra.

De acordo com Marisa Feffermann (2013:2) a luta contra o genocídio da juventude negra é uma das bandeiras unificadas entre os movimentos negros contemporâneos no Brasil. Ao longo do texto, apresentamos três pesquisas que atestam a elevada violência e vulnerabilidade que a juventude negra e pobre no Brasil se encontra, ocasionando ser a camada da população que mais morre. Tal fato tem constituído uma série de mobilizações e pressões que fizeram, por exemplo, essa denúncia chegar ao poder legislativo brasileiro.

Para uma melhor compreensão das denúncias da existência de um genocídio da população negra, é importante relembrar que, no Brasil, historicamente, a luta contra o racismo e a violência racial tem sido protagonizada pelos movimentos negros. De acordo com Nilma Lino Gomes (2017), podemos caracterizar esses movimentos de diferentes maneiras, contudo existe uma característica comum entre eles: a postura de enfrentamento ao racismo.

\footnotetext{
Entende-se como Movimento Negro as mais diversas formas de organização e articulação das negras e dos negros politicamente posicionados na luta contra o racismo e que visam à superação desse perverso fenômeno na sociedade. Participam dessa definição os grupos políticos, acadêmicos, culturais, religiosos e artísticos com o objetivo explícito de superação do racismo e da discriminação racial, de valorização e afirmação da história e da cultura negras no Brasil, de rompimento das barreiras racistas impostas aos negros e às negras na ocupação dos diferentes espaços e lugares na sociedade (Gomes, 2017:23-24).
}

A compreensão do cenário de violência racial contra a população negra enquanto genocídio, protagonizada principalmente por estes movimentos, como se verá abaixo, é um exemplo de como os movimentos sociais procuram teorizar politicamente e propor mudanças sobre e para as situações sociais injustas, tal como discute Gomes (2017) e Renato Perissinoto e José Szwako (2017).

\footnotetext{
${ }^{1}$ Para evitar repetições, utilizamos a abreviação “GNB”, para referir a esta obra.
} 
O texto está dividido em quatro seções, com exceção desta introdução e das considerações finais. Na primeira, é feita uma contextualização da definição de genocídio. Já na segunda seção, apresentamos e analisamos a obra GNB de Abdias Nascimento. Na terceira seção, discutimos o cenário de violência contra os jovens negros e a luta contra o genocídio da juventude negra, apresentando três mobilizações que atuam contra tal situação. Por fim, na quarta e última seção, são feitas considerações sobre como os movimentos sociais utilizam do termo genocídio como estratégia política para teorizar e educar sobre e com a situação social da população negra.

\section{As controvérsias de uma definição: o que é genocídio?}

A definição de genocídio não é uma novidade nos debates políticos e acadêmicos, e dessa forma, existe uma necessidade em contextualizar o seu uso "sob diferentes prismas, como por exemplo, na concepção jurídica e política, acadêmica e na utilização conceitual utilizada nas políticas públicas" (Alves, 2017:2). A definição sobre o que é genocídio e o questionamento de quais são as categorias que vítimas e perpetradores do genocídio usam para nomear-se e entender-se uns aos outros figuram como preocupações centrais nos e dos estudos sobre genocídio (Hinton, 2016:21).

O termo genocídio foi criado pelo advogado polônes Raphael Lemkin² em 1944, no contexto após a Segunda Guerra Mundial e deriva da palavra grega genos (raça, nação, tribo) e do sufixo latino cídio (matar). De acordo com Antonio Monteiro (1999), o genocídio integra um conjunto de condutas delituosas revestidas de excepcional gravidade, conhecidas como crimes hediondos. Por apresentar esse caráter de gravidade, para Joyce Alves (2017:9) o termo genocídio tem uma importância política com "teor denunciativo, provocador e mobilizador" que acarreta incômodo, sobretudo para quem pratica, por possuir uma "força emocional e conceitual” (Rosenberg, 2016:32 [Tradução livre]).

Ainda segundo Monteiro (1999), apesar de o conceito ter sido criado somente em 1944, as práticas que podem ser interpretadas enquanto genocídio são constantes na história da humanidade, diversos acontecimentos historicamente apresentaram uma linha de comportamento genocida. Entretanto, isso não quer dizer que os genocídios são iguais ou que

\footnotetext{
${ }^{2}$ De acordo com Hinton (2016), Raphael Lemkin é tido como o fundador do campo dos estudos sobre genocídio, e o Holocausto e a Convenção para a Prevenção e a Repressão do Crime de Genocídio da Organização das Nações Unidas (ONU) são dois marcos fundamentais. Assim, para Hinton (2016:18), a tentativa nazista se apresenta como um ponto de inflexão que estimula a luta pelos direitos humanos e, por conseguinte, a emergência dos estudos sobre genocídio.
} 
seguem um modelo. De acordo com Sheri Rosenberg (2016), os genocídios se diferenciam a depender dos seus fatores sociais, políticos e históricos.

Em 1948, após a pressão de diferentes países e agências internacionais, a Organização das Nações Unidas (ONU) elaborou a Convenção para a Prevenção e a Repressão do Crime de Genocídio. Esse documento reconhece que as práticas de genocídio causaram grandes perdas à humanidade e indica que os países devem se comprometer em sua prevenção e punição. $\mathrm{O}$ artigo $2^{\circ}$ traz a definição de genocídio, entendendo-o enquanto atos cometidos com "intenção de destruir no todo ou em parte, um grupo nacional, étnico, racial ou religioso". Sendo assim, elenca os seguintes atos:

a) Assassinato de membros do grupo;

b) Atentado grave à integridade física e mental de membros do grupo;

c) Submissão deliberada do grupo a condições de existência que acarretarão a sua destruição física, total ou parcial;

d) Medidas destinadas a impedir os nascimentos no seio do grupo;

e) Transferência forçada das crianças do grupo para outro grupo. ${ }^{3}$

Para Monteiro (1999:83), essa definição de genocídio apresenta alguns limites. Um deles é que o "genocídio cultural" não é delimitado enquanto prática integrante do crime. Outro é a exclusão dos grupos políticos, econômicos e culturais como possíveis vítimas de extermínios intencionais. Essa convenção, ao delimitar (e, portanto, amparar) um conjunto de grupos, acabou por deixar outros desprotegidos e analiticamente invisíveis. A partir desse entendimento, Alexander Hinton (2016:22 [Tradução livre]) sugere definir o genocídio como "a tentativa mais ou menos coordenada de destruir um grupo de pessoas desumanizado por causa de quem são". Com essa definição, o autor indica que conseguimos abarcar desde genocídios que foram planejados pelo Estado até os que são realizados de maneira desordenada e difusa.

Por esse ângulo, ao entender o genocídio através de um campo mais amplo, é possível realçar as diferentes possibilidades que coletividades podem ser destruídas, seja física, biológica, cultural ou politicamente, por meio de forças do Estado ou atores não estatais. Soma-se a isso, um entendimento que o genocídio pode desdobrar-se durante o curso de

\footnotetext{
${ }^{3}$ Disponível em:

https://www.mprj.mp.br/documents/20184/99247/Convencao_para_a_prevencao_e_repressao_do_crime_de_gen oc.pdf
} 
grandes períodos e não necessariamente em curtas durações ou períodos específicos (Hinton, 2016). Rosenberg (2016) chama atenção para esse caráter processual dos genocídios, procurando compreendê-los não apenas como acontecimentos, mas como processos e fluxos que apresentam continuidades e mudanças. Isso quer dizer que "o genocídio é um fenômeno social complexo e variável e não um termo estanque" (Rosenberg, 2016:30 [Tradução livre]).

Compreendendo como um processo, Rosenberg (2016:31) registra que os contextos causais dos genocídios podem apontar para práticas discriminatórias anteriores ao início do extermínio em massa. Nesse sentido, a autora aborda sobre a necessidade em pensar no "genocídio por desgaste", também chamado de "genocídio em câmera lenta". Não se trata de uma nova definição de genocídio, mas uma forma de complexificá-la, direcionando atenção para métodos indiretos de destruição, pois "as práticas e políticas de genocídio por desgaste incluem primeiro, mas não somente, o deslocamento forçado, a privação de saúde e cuidados sanitários e de alimentos e a violência sexual” (Rosenberg, 2016:34 [Tradução livre]).

Outro ponto que merece ser ressaltado é a ligação existente entre o extermínio e a construção de discursos que o legitimam. Rômulo Morais (2016) analisa como, de modo geral, a sociedade brasileira e, especificamente, as instituições jurídicas relacionadas à infância e juventude no estado do Pará circulam e produzem discursos que ratificam o extermínio da juventude popular e negra, sendo assim, "discursos que matam”. Dessa forma, compreende-se que os extermínios e genocídios, no caso, da juventude negra e pobre no Brasil, aportam-se não apenas em mortes, mas em processos discursivos constantes e efusivos.

Se por um lado, o Brasil foi um dos signatários da Convenção para a Prevenção e a Repressão do Crime de Genocídio logo após sua publicação pela ONU em 1951, por outro, de acordo com Ana Flauzina (2013), os Estados Unidos só se tornou signatário quase quarenta anos após a ratificação por outros países, em 1986. Flauzina (2013) demonstra a atuação dos movimentos negros através do Civil Rights Congress (CRC) em 1951, quando acusaram o governo estadunidense da prática de genocídio contra a população negra.

Através de sua campanha contra o genocídio, o CRC brevemente expandiu as fronteiras intelectuais do debate contemporâneo racial, oferecendo o genocídio como uma teoria alternativa para explicar as relações raciais americanas. A aplicação deste novo conceito para a situação dos Afro-americanos, que ofendeu a muitos negros e brancos, adicionou uma perspectiva mais nítida, mais emocional ao crescente debate internacional sobre o racismo americano. Embora o estudo do CRC não tenha conseguido estabelecer que o governo dos Estados Unidos era culpado de cometer genocídio, o grupo identificou com precisão o governo federal como a entidade que possuía o poder suficiente para reduzir a enorme discriminação que, obviamente, existia (Martin, 1997 apud Flauzina, 2013:6). 
A citação acima demonstra ao menos três das potencialidades da denominação de genocídio. Uma é o genocídio ser uma definição marcante e incontestável do racismo e das desigualdades raciais. Outra diz respeito à responsabilização do Estado como agente encarregado de enfrentar e combater as práticas genocidas. Já sobre o genocídio como uma teoria alternativa para compreender as relações raciais, podemos entrelaçar ao Brasil, quando o intelectual e militante negro Abdias Nascimento intitula uma de suas obras como "O genocídio do negro brasileiro", propondo uma leitura denunciativa das violências raciais ante uma compreensão do Brasil como uma democracia racial.

\section{“O genocídio do negro brasileiro", por Abdias Nascimento}

Abdias Nascimento ${ }^{4}$ foi um dos intelectuais da e na luta antirracista, com atuação em diferentes fases do movimento negro brasileiro. De caráter ensaístico, a obra GNB foi publicada pela primeira vez em 1978. Foi inicialmente escrita para apresentação no Segundo Festival Mundial de Artes e Culturas Negras e Africanas (FESTAC'77), que foi realizado na Nigéria, em 1977. Porém, esse trabalho foi rejeitado pelo Festival. No prólogo do livro, Abdias Nascimento conta os detalhes dessa rejeição, que teve os seus motivos ocultados. O trabalho não foi aceito pois a apresentação iria desmascarar a imagem do Brasil como uma democracia racial.

Na epígrafe do livro, há duas definições de genocídio, ambas extraídas de verbetes de dicionários. A primeira aponta o genocídio como a utilização de planos sistemáticos (como morte, injúria corporal, prevenção de nascimento, impossíveis condições de vida) voltados para o extermínio de um grupo racial, político ou cultural ou para destruir parte desse grupo, como a língua, religião ou cultura. Já a segunda traz o genocídio como a recusa ao direito de existência a grupos humanos, seja pela exterminação dos indivíduos ou desintegração de instituições políticas, linguísticas, religiosas etc.

A obra GNB faz um panorama da sistematicidade do racismo brasileiro. A começar pelos mitos sobre a escravidão, atentando para o mito do senhor benevolente e do africano livre, com destaque para a exploração sexual da mulher africana como fundamento da miscigenação e das violências raciais no/do Brasil (Nascimento, 2016). O pós-abolição é

\footnotetext{
${ }^{4}$ Abdias Nascimento nasceu em 1914 e faleceu em 2011. Foi um ativista social brasileiro, escritor, político, artista plástico e dramaturgo. Participou da Frente Negra Brasileira nos anos 30 e fundou o Teatro Experimental do Negro (1944-1968). Auxiliou na fundação do Movimento Negro Unificado (MNU) em 1978. Pelo Partido Democrático Trabalhista (PDT) foi deputado federal (1983-1987) e senador (1997-1999). Fundou em 1981 o Instituto de Pesquisa e Estudos Afro-Brasileiros (IPEAFRO). (Cf. http://ipeafro.org.br/personalidades/abdiasnascimento/ - Acesso em 25/11/2018).
} 
enunciado a partir dos processos de embranquecimento da raça, sobretudo através da miscigenação e da imigração. A imagem do Brasil enquanto uma harmonia racial no exterior é contrastada com a discussão racial extremamente proibida e os constantes casos de discriminação racial no interior do país. Outro campo de análise em Nascimento (2016) é a cultura e a arte. $\mathrm{O}$ embranquecimento cultural é tido como uma das formas de genocídio e atenta-se às complexidades relacionadas à existência de culturas africanas no Brasil. Nas palavras do autor:

\begin{abstract}
Devemos compreender "democracia racial" como significando a metáfora perfeita para designar o racismo estilo brasileiro: não tão óbvio como o racismo dos Estados Unidos e nem legalizado qual o apartheid da África do Sul, mas institucionalizado de forma eficaz nos níveis oficiais do governo, assim como difuso e profundamente penetrante no tecido social, psicológico, econômico, político e cultural da sociedade e do país. Da classificação grosseira dos negros como selvagens e inferiores, ao enaltecimento das virtudes da mistura de sangue como tentativa de erradicação da "mancha negra"; da operatividade do "sincretismo" religioso à abolição legal da questão negra através da Lei de Segurança Nacional e da omissão censitária manipulando todos esses métodos e recursos - a história não oficial do Brasil registra o longo e antigo genocídio que se vem perpetrando contra o afro-brasileiro (Nascimento, 2016:111).
\end{abstract}

A definição de um genocídio da população negra no cerne das relações raciais brasileiras por Abdias Nascimento é um confronto ao entendimento de um país com uma harmonia racial. Nesse sentido, a difusão da ideia de uma democracia racial funcionaria como uma ratificação do genocídio do negro brasileiro, pois ignora as desigualdades e discriminações raciais social e historicamente constituídas. O livro GNB pode ser considerado como parte de um conjunto de trabalhos que "desde a década de 1970, deslocavam a crença na democracia racial brasileira" (Figueiredo; Grosfoguel, 2009:223).

Nesse sentido, cabe contextualizar esse período do final da década de 1970, referente à primeira publicação de GNB, que resulta nas tentativas de embranquecimento da população brasileira e nas interpretações desse Brasil enquanto "espetáculo da miscigenação" desde o início do século $\mathrm{XX}$ com fortes incidências do racismo científico em suas elaborações, conforme apresenta Lilia Schwarcz (1993). Tendo em vista as fortes críticas feitas por Abdias Nascimento a tais políticas e interpretações podemos entender em sua argumentação como que "sob o prisma de diversas situações, o negro está destinado ao aniquilamento, à exclusão e ao extermínio, dentro de uma lógica que é colonialista, branca e violenta” (Alves, 2017:10).

Portanto, Abdias Nascimento delimita ao longo de sua obra um conceito sistêmico de genocídio, trata-se de uma destruição que se difunde por diferentes dimensões da vida social, cultural, religiosa, artística, econômica e psicológica. Em síntese, para além de violências 
físicas, o GNB reflete sobre as violências simbólicas e epistêmicas que são investidas contra a população negra no Brasil, arquitetando um conceito de genocídio sistêmico e estrutural.

\title{
A luta antirracista contra o genocídio da juventude negra
}

Nas últimas décadas, segundo Feffermann (2013), devido ao recrudescimento do capitalismo e do racismo, houve um acirramento das desigualdades e violências raciais, com isso as pautas dos movimentos negros também se alteraram, sobretudo porque entenderam que era preciso ações mais abrangentes no enfrentamento ao racismo. Nesse interim, com o passar dos anos, os movimentos negros não modificam o fundamento das reivindicações, mas "vão se enveredando, possibilitando novas formas de ação. Um dos principais pontos de unificação dos vários militantes do movimento negro é o genocídio do povo negro, em especial dos jovens" (Feffermann, 2013:13).

O combate ao fim do genocídio de negros/as, no Brasil, tem sido realizado pela militância antirracista com base em dados estatísticos de algumas pesquisas (Alves, 2017). As pesquisas mais conhecidas que atestam e embasam a denúncia de genocídio da juventude negra são o Atlas e o Mapa da Violência ${ }^{5}$. O Atlas da Violência é uma pesquisa desenvolvida pelo Instituto de Pesquisa Econômica Aplicada (IPEA) em parceria com o Fórum Brasileiro de Segurança Pública (FBSP). Dentre as principais evidências expostas no Atlas está a de que o Brasil é um país com altas taxas de violência em comparação a outros países do mundo. No que diz respeito ao sexo e à idade das vítimas, o Atlas confirma que a violência letal é extremamente acentuada contra homens jovens. A cor/raça das vítimas é expressa nessa pesquisa, ao evidenciar que

\begin{abstract}
Em 2016, por exemplo, a taxa de homicídios de negros foi duas vezes e meia superior à de não negros $(16,0 \%$ contra $40,2 \%)$. Em um período de uma década, entre 2006 e 2016, a taxa de homicídios de negros cresceu $23,1 \%$. No mesmo período, a taxa entre os não negros teve uma redução de 6,8\%. Cabe também comentar que a taxa de homicídios de mulheres negras foi $71 \%$ superior à de mulheres não negras (Cerqueira et al., 2018:40).
\end{abstract}

Esses dados levaram à conclusão de que no Brasil "é como se, em relação à violência letal, negros e não negros vivessem em países completamente distintos" (Cerqueira et al.,

\footnotetext{
5 Destaca-se também o Índice de Vulnerabilidade Juvenil à Violência (IVJ), desenvolvido pela Secretaria Nacional de Juventude (SNJ) em parceria com o Fórum Brasileiro de Segurança Pública (FBSP). Suas principais conclusões também direcionam para o fato já demonstrado pelo Atlas e o Mapa da Violência que, no Brasil, na atualidade, a violência tem atingido principalmente jovens negros moradores de periferias.
} 
2018:40). Já o Mapa da Violência, pesquisa realizada pelo sociólogo Julio Jacobo Waiselfisz, analisa a quantidade de homicídios por armas de fogo no Brasil. A partir da cor/raça, idade e sexo das vítimas, o Mapa também constata uma acentuada seletividade expressa no alto número de mortes de jovens negros. Em 2003, foram cometidos 13.224 homicídios por armas de fogo na população branca em todo o Brasil, em contrapartida, nesse ano, para a população negra (incluindo pretos e pardos) esse número foi de 20.291 homicídios. Já em 2014, a quantidade de mortes de brancos/as diminuiu para 9.766, o que representa uma queda de 26,1\%. Porém, em 2014, o número de vítimas negras passou para 29.813, representando um aumento de 46,9\% (Waiselfisz, 2016:55).

Cabe salientar que essa grande maioria de homicídios de jovens negros e pobres envolve forças policiais na execução. Existe uma dificuldade em mensurar as mortes causadas por intervenções policiais pois têm-se uma subnotificação da autoria (assim como da vítima) dos homicídios, porém destaca-se que "frequentemente as polícias brasileiras têm sido acusadas de violações de direitos e de serem violentas, o que reforça a necessidade de registros fidedignos" (Brasil, 2017:28-29). Além disso, as armas de fogo são apontadas pelo Atlas da Violência como difusoras da violência letal no país.

De fato, existem inúmeros fatores a impulsionar a violência letal no país, como a profunda desigualdade econômica e social, a inoperância do sistema de segurança pública, a grande presença de mercados ilícitos e facções criminosas e o grande número de armas de fogo espalhadas pelo Brasil afora. (...) A questão aqui é que, não fosse essa legislação que impôs um controle responsável das armas de fogo, a taxa de homicídios seria ainda maior que a observada (Cerqueira et al., 2018:71).

A citação se refere ao Estatuto do Desarmamento (2003) que atualmente encontra riscos de facilitação para a posse e porte de armas no Brasil ${ }^{6}$. Segundo Waiselfisz (2016:15), praticamente $95 \%$ da utilização de armas de fogo com finalidade letal, ou ainda, com intuito de ocasionar morte, no Brasil, tem como objetivo o extermínio intencional do próximo. Nesse sentido, as armas de fogo detêm forte ligação com a noção de genocídio da juventude negra, representando como na contemporaneidade "são dispostas com o objetivo de provocar a destruição máxima de pessoas e criar 'mundos de mortes', (...) nas quais vastas populações são submetidas a condições de vida que lhes conferem o estatuto de "mortos-vivos"” (Mbembe, 2018:71).

\footnotetext{
${ }^{6}$ No dia 15 de janeiro de 2019, o presidente Jair Bolsonaro assinou um decreto que altera o Estatuto do Desarmamento (Confira: https://g1.globo.com/politica/noticia/2019/01/15/bolsonaro-assina-decreto-que-facilitaposse-de-armas.ghtml - Acesso em: 08 mar. 2019).
} 
Achille Mbembe (2018) denomina como necropolítica as configurações políticas que residem na capacidade em decidir quem pode viver e quem deve morrer. A permissão para viver e a ordem para morrer estão circunscritas, segundo Mbembe (2018:41), no poder soberano que tem "a capacidade de definir quem importa e quem não importa, quem é 'descartável' e que não é’. Em uma robusta argumentação, esse filósofo camaronês nos informa que existe uma submissão da vida ao necropoder que se edifica na qualidade de condutas que têm como finalidade exterminar determinados grupos populacionais e criar "mundos de morte".

Esses dados e interpretações têm contribuído para denominar essas violências como genocídio da juventude negra. A atualidade desse genocídio pode ser observada a partir da existência de movimentos sociais e ações coletivas mobilizadas para denunciá-lo e combatê$10^{7}$.

O “Reaja ou será Morto! Reaja ou será Morta!” surgiu em 2005, em Salvador/BA, e é um movimento que luta contra "a brutalidade policial, pela causa antiprisional e pela reparação aos familiares de vítimas do Estado (execuções sumárias e extrajudiciais) e dos esquadrões da morte, milícias e grupos de extermínio" ${ }^{8}$. Dentre as suas principais ações está a realização da Marcha Internacional contra o Genocídio do Povo Negro, que teve sua primeira edição em 2013 e até o momento tem ocorrido todos os anos e vem se difundindo por várias cidades do país e do mundo. De acordo com informações do site do "Reaja!", um dos principais motivos que provocaram a criação desse movimento foi a percepção de que o "governo tinha, no estado penal e no racismo, fundamento para uma política de genocídio caracterizada pelas mortes de milhares de jovens negros desovados como animais às margens de Salvador e Região Metropolitana" ${ }^{\text {" }}$. Podemos perceber que o movimento surge a partir da percepção de violências raciais sintetizadas na morte de jovens negros. Ademais, esse movimento emerge de forma contenciosa com marchas de rua e de forma dialógica e chamativa expressa em seu próprio nome que, de modo imperativo, ordena e conclama uma reação à morte da população negra, explicitando que caso não (re)aja será morto, indicando assim as vítimas potenciais de violência e morte.

Já o movimento "Mães de Maio", surgiu após a morte de mais de 500 jovens (em sua maioria, pobres e negros) durante o mês de maio de 2006 no estado de São Paulo. A grande

\footnotetext{
${ }^{7}$ Registra-se que entendemos aqui movimento social, conforme Melucci (1989), como uma ação coletiva que tem por base a solidariedade (na forma de identidade coletiva) e o conflito direto que permite romper os limites do sistema em que a ação ocorre.

${ }^{8}$ Disponível em http://www.reajaouseramortx.com/p/quem-somos.html. Acesso em 03 dez. 2018

${ }^{9}$ Disponível em http://www.reajaouseramortx.com/p/quem-somos.html. Acesso em 03 dez. 2018
} 
parte dos assassinatos envolviam a participação de policiais ${ }^{10}$. O grupo é formado principalmente pelas mães e familiares das vítimas. A demanda por políticas públicas de reparação psicológica para as vítimas de violência do Estado, sobretudo os familiares de jovens negros e pobres mortos é uma das suas principais reivindicações. Cabe relacionar as "Mães de Maio" ao que Hinton (2016) denomina de "sequelas dos genocídios", isto é, as consequências que circundam traumas e memórias desses crimes. Para esse autor, é preciso questionar "como lidam os sujeitos com a experiência e as sequelas/consequências/realizações do genocídio com o passar do tempo" (Hinton, 2016:20 [Tradução livre]). Nesse caminho, o movimento "Mães de Maio" indica como as violências têm consequências múltiplas e variadas dinâmicas e, logo, as suas formas de combatê-la são diversas e com distintos focos.

O movimento "Nós temos um sonho", criado em 2015 pela cantora, compositora e intérprete Luiza da Iola em Belo Horizonte/MG busca através das artes e da educação lutar por diversas causas da população negra. Trata-se de um coletivo ${ }^{11}$ de artistas negros/as que integraram o videoclipe denominado "Deixa o Erê Viver", que foi lançado em dezembro de 2016, no Youtube.

Lu Daiola conta que a ideia veio a partir da notícia da chacina dos cinco jovens no subúrbio do Rio de janeiro, em 2015 (...). Assim surgiu o clipe, baseado nessa ideia de como os tributos musicais alavancam visibilidade sobre essas questões. Um protesto artístico", diz. (...) "A canção denuncia os crimes sedimentados e naturalizados num cotidiano de perseguição silenciosa, cravado por balas, que impedem nossos filhos de voltarem para casa. Esta iniciativa é uma resposta dos artistas ao genocídio de jovens negros e ao racismo institucionalizado" ("Deixa o Erê Viver: um canto pela Juventude Negra", Revista Senso, 24/05/2017). ${ }^{12}$

A campanha desse movimento procura a partir da arte combater a violência contra a juventude negra. Esta mobilização caracteriza-se pelos potentes entrelaçamentos entre arte e ativismo que exploram a partir da internet, formas de visibilidade e denúncia social. O videoclipe lançado pelo projeto é referente à música intitulada "Deixa o erê viver", de composição de Sérgio Pererê, Tamara Franklin e Douglas Din.

\footnotetext{
10 Disponível em https://www.brasildefato.com.br/2016/05/13/surgido-da-dor-maes-de-maio-se-tornamreferencia-no-combate-a-violencia-do-estado/ - Acesso em 03 dez. 2018.

${ }^{11}$ É importante destacar que embora entendamos até aqui as três mobilizações como movimentos sociais e ações coletivas, o "Nós temos um sonho" se autodeclara como "coletivo". De acordo com Neto (2018: 9) os coletivos são "organizações de participação que não possuem pretensão de representação", que evocam a "biografia de seus membros como maneira de legitimar sua presença e atividades no espaço público" e que não apresentam "laços duradouros com outras organizações do Estado, do mercado ou da sociedade civil", diferenciando-os assim dos movimentos sociais, partidos, ONGs e associações.

12 Disponível em https://revistasenso.com.br/2017/05/24/deixa-o-ere-viver-um-canto-pela-juventude-negra/ Acesso em: 22 fev. 2019.
} 
Deixa o erê brincar/ Deixa o erê viver/ Deixa o erê crescer pra ser doutor e assinar a nova lei/ Deixa o erê cantar/ Deixa o erê saber que o seu bisavô não foi escravo e sim um verdadeiro rei/ Não mate o meu menino/ Não corte as nossas asas/ Eu quero ter a paz de saber que o meu filho vai voltar pra casa. ${ }^{13}$

O pedido de permissão para a vida, expresso na letra da música, relaciona-se ao que Mbembe (2018) assevera como a decisão do poder sobre quem pode viver e quem deve morrer. Já o erê refere-se a uma fase nascente dos orixás, entidades sagradas da religião de matriz africana candomblé e, nessa música, pode ser lido como uma criança ou um jovem. A letra também expressa pedidos de permissão para atos sutis da vida de uma criança/jovem, como brincar e cantar. Além de uma súplica para "deixar crescer", seguir o fluxo de um estágio decisivo para a sequência da vida, a juventude. Podemos visualizar a letra e a campanha "Deixa o Erê Viver", do movimento "Nós temos um sonho", a partir do conceito de ferocidade poética, proposto por Franciane Silva, que se refere à "possibilidade da encenação da violência em textos literários ser permeada por gestos de poeticidade. Esse lirismo intensifica o efeito do ato violento, ao mesmo tempo em que traz uma carga de ternura para aquilo que é encenado, acentuando a nossa sensibilidade” (Silva, 2018:168).

"Deixa o Erê Viver" é um bom exemplo da encenação da violência de forma poética com o intuito de causar indignação frente à violência sofrida pela população negra, em especial pela juventude. Os três movimentos acima descritos, "Reaja!", "Mães de Maio" e "Nós temos um sonho" conformam diferentes reações contra a violência racial, cometida principalmente pelo Estado. Ambos movimentos emergem de situações específicas que estimulam a necessidade em enfrentar atos e práticas genocidas. Enquanto o "Reaja!" focaliza os protestos e marchas de rua, o "Mães de Maio" é um movimento idealizado a partir das dores de mães que perderam os seus filhos. Já o "Nós temos um sonho" elege a manifestação artística como forma de denúncia social. Esses movimentos compõem uma trama de mobilizações que convergem no pedido e exigência do direito à vida da população negra.

\footnotetext{
Há um movimento novo no cenário protagonizado por esses jovens [negros]. A raça, usada e vista como fonte de extermínio pela sociedade, é por eles transformada e ressignificada como símbolo de afirmação, de luta e emancipação. Os cabelos crespos, as religiões de matriz africana, o mundo da cultura, da música, a entrada na universidade via cotas, o empreendedorismo negro e juvenil, principalmente no mundo da comunicação e do design, são alguns dos espaços que têm sido tomados, hoje, pelos jovens negros e negras. Em todos esses espaços eles levam a denúncia: Parem de nos matar (Gomes; Laborne, 2018:22).
}

\footnotetext{
${ }^{13}$ Disponível em https://www.youtube.com/watch?v=JX4Mx0sDFS4 - Acesso em: 22 fev. 2019.
} 


\section{Genocídio da população negra: uma compreensão política das violências raciais}

Como estamos discutindo ao longo do texto, a denominação e denúncia da violência contra a população negra como genocídio é feita, principalmente, pelos movimentos negros, seja por meio de um dos seus integrantes intelectuais, Abdias Nascimento, seja através de movimentos e mobilizações, como o "Reaja!", "Mães de Maio" e "Nós temos um sonho".

As pesquisas sobre violência, apresentadas na última seção, apontam a elevada quantidade de homicídios da juventude negra, entretanto, não utilizam o termo genocídio, com exceção do prefácio da publicação do Mapa da Violência de 2016, em que a ex-ministra Luislinda Dias de Valois Santos reconhece a existência de um "genocídio da juventude negra periférica" (Waiselfisz, 2016:7). Em ambas as pesquisas, há menções da situação de violência como matança generalizada e/ou extermínio, além da responsabilização, em grande medida, do Estado pelo próprio ato de matar ou por sua omissão. Segundo Gomes e Laborne (2018), o movimento negro tem feito a denúncia da situação de violência racial indo além da ideia de extermínio e politizando-a como genocídio.

Esse fato nos faz sinalizar, de acordo com Perissinotto e Szwako (2017), como os movimentos sociais criticam publicamente sistemas considerados injustos e apresentam análises sobre a realidade. Devido a isso, os movimentos sociais podem ser considerados como produtores de teoria política e, portanto, teóricos políticos coletivos.

[...] como conjunto de atrizes e atores que produzem ideias no momento em que agem publicamente, os movimentos sociais partilham com a teoria política a vocação da crítica ao viés sistemático encontrado no contexto em que atuam. São, nesse sentido, "autores em ação" e, por conseguinte, teóricos políticos coletivos (Perissinoto; Szwako, 2017:241).

Em grande medida, segundo esses autores, os movimentos sociais em suas lutas realizam um processo de construção de teoria política que envolve três fatores, por vezes, simultâneos: i) formulam/produzem propostas para enfrentamento de desigualdades e discriminações; ii) elaboram uma crítica sistemática ao viés desigual e discriminatório da sociedade e iii) apresentam um projeto alternativo de superação desse viés (Perissinotto; Szwako, 2017:246).

No caso analisado, os movimentos sociais não se encarregam apenas de reivindicar e apresentar outra interpretação sobre as relações raciais no Brasil, mas sobretudo, de reeducar a sociedade. Segundo Gomes (2017:14), o movimento negro brasileiro é um "educador, produtor de saberes emancipatórios e um sistematizador de conhecimentos sobre a questão 
racial no Brasil". Os saberes produzidos pela população negra e que são politicamente sistematizados pelo movimento negro são criações e recriações que significam, nas palavras da autora, "a intervenção social, cultural e política de forma intencional e direcionada dos negros e negras ao longo da história, na vida em sociedade, nos processos de produção e reprodução da existência" (Gomes, 2017:67).

Devido, em grande parte, às pressões e demandas dessas mobilizações contra o genocídio da juventude negra, em 2015, a Câmara e o Senado Federal criaram comissões parlamentares de inquéritos, as chamadas CPIs, para investigar o assassinato da juventude negra $^{14}$. Dentre as principais conclusões a que chegaram, destacam-se a denominação da violência contra os jovens negros no Brasil como genocídio e a responsabilização do Estado, especificamente o papel da polícia e do judiciário, frente a essa problemática.

Esta CPI, em consonância com os anseios do Movimento Negro, bem como com as conclusões de estudiosos e especialistas do tema assume aqui a expressão GENOCÍDIO DA POPULAÇÃO NEGRA como a que melhor se adequa à descrição da atual realidade em nosso país com relação ao assassinato dos jovens negros (Farias, 2016:33-34).

As pessoas negras e pobres desse País, em especial sua juventude, vem sendo vítima de um tipo especial e diferente de genocídio. (...) O genocídio com o qual esta Comissão entrou em contato é uma matança simbólica de todo um grupo em meio a uma quantidade absurda de mortes reais (Gomes, 2015:32-33).

Podemos constatar, a partir dos excertos acima, como o movimento negro é responsável por denominar a situação de violência contra a população negra como genocídio. Além disso, podemos compreender que existe um uso de pesquisas acadêmico-científicas pelos movimentos sociais para emergirem suas demandas e denúncias. Eventualmente, as pesquisas são responsáveis por evidenciar e constatar as situações de desigualdade e discriminação que os movimentos sociais denunciam. A politização e a compreensão das violências contra a população negra como um genocídio indicam uma estratégia dos movimentos em instaurarem incômodo na sociedade brasileira e no próprio Estado que, salvo raras exceções, historicamente, têm sido inertes ao enfrentamento e combate de tais atos.

\footnotetext{
14 Na Câmara de Deputados, a CPI "Homicídios de jovens negros e pobres" foi criada em 2015 e buscou apurar os motivos e consequências da morte de jovens negros e pobres no Brasil. Já no Senado Federal, a CPI “Assassinato de jovens", também criada em 2015, teve como intuito "investigar o assassinato de jovens no Brasil. (...) identificar as causas e os principais responsáveis pela violência letal que assaca nossa juventude, a fim de criar mecanismos para prevenir e combater este grave problema" (Farias, 2016:4). Apesar de não estar explícito em seu título e em seus objetivos, a CPI instaurada no Senado também evidenciou a população jovem negra.
} 
Nas palavras de Sales Augusto dos Santos (2015), com relação ao genocídio da população negra no Brasil, "há o silêncio nos e dos tribunais, nas e das universidades, entre outros espaços e/ou instituições de prestígio, influência, poder e mando, embora haja o grito e a dor das mães, dos pais, parentes e amigos daqueles jovens negros de quem se arrebata a vida coletivamente" (Santos, 2015:658).

Provocar incômodo ao nomear e politizar o extermínio é parte da construção de desestabilizações. Ainda segundo Gomes (2017:62), as lutas educativas emancipatórias, como as do movimento negro brasileiro, despertam conflitos pois propiciam a elaboração de imagens e subjetividades desestabilizadoras que provocam "a capacidade de espanto e de indignação e uma postura de inconformismo" com relação às realidades opressoras e injustas.

\section{Considerações finais}

A análise que procuramos tecer ao longo deste artigo fez uma breve definição do conceito de genocídio e realizou uma leitura da obra GNB publicada no século XX e de mobilizações de movimentos sociais na luta contra o genocídio da população jovem negra no século XXI. A partir das lentes do conceito de genocídio, foi possível entender que o genocídio é um conceito que explicitamente responsabiliza as instituições (estatais ou nãoestatais) e que é dotado de uma carga emocional.

Em Abdias Nascimento (2016), enunciam-se diversas facetas da história e cultura afro-brasileira, e relata-se como a população negra foi e é violentada nas diferentes dimensões da vida social. Nessa obra, a ideia de genocídio é mobilizada como um entendimento alternativo e contrário à ideia de democracia racial. Já as atuais mobilizações e movimentos demonstram-nos que o elevado número de mortes de jovens negros (pobres e moradores de periferias) suscitam uma forte denúncia de genocídio mais restrita e direcionada, sobretudo, para as mortes físicas. Podemos pensar que essa restrição se dá por ser preciso denunciar o processo brutal de submissão de vidas negras a um, nas palavras de Mbembe (2018), necropoder. Essa denúncia emerge por diferentes objetivos e em variadas plataformas, como os protestos de rua, os ativismos através da arte e internet e os acompanhamentos de mães e familiares de jovens mortos.

A trama costurada ao longo deste artigo permite apreender que a compreensão das violências raciais brasileiras enquanto um genocídio da população negra tem sido uma estratégia política dos movimentos sociais negros, que podem ser vistos como verdadeiros "teóricos políticos coletivos" e "educadores" da/sobre a situação social da população negra. 
Tal estratégia compõe uma constelação de objetivos e dinâmicas, que cabe em futuras pesquisas investigar, mas que é possível vê-la como a potencialidade em instaurar incômodo e provocar desestabilizações frente à opressão e injustiça. Essas estratégias têm surtido efeitos como, por exemplo, a discussão passar a ser feita e investigada no poder legislativo brasileiro.

\section{Referências}

ALVES, Joyce A. de A. (2017), "Violência racial e a construção social do 'genocídio da população negra", in $41^{\circ}$ Encontro Anual da ANPOCS, outubro 2017, Caxambu/MG [Consult. 18-09-2019]. Disponível em http://anpocs.com/index.php/encontros/papers/41-encontro-anual-da-anpocs/spg4/spg271/11020-violencia-racial-e-a-construcao-social-do-genocidio-da-populacao-negra/file

BRASIL. Presidência da República. Secretaria de Governo (2017), Índice de vulnerabilidade juvenil à violência 2017: desigualdade racial, municípios com mais de 100 mil habitantes. Secretaria de Governo da Presidência da República, Secretaria Nacional de Juventude e Fórum Brasileiro de Segurança Pública. São Paulo, Fórum Brasileiro de Segurança Pública [Consult. 18-09-2019]. Disponível em http://www.forumseguranca.org.br/wpcontent/uploads/2018/10/FBSP_Vulnerabilidade_Juveni_Violencia_Desigualdade_Racial_2017_R elat\%C3\%B3rio.pdf

CERQUEIRA, Daniel, et al (2018), Atlas da violência 2018. Rio de Janeiro, IPEA-FBSP [Consult. 1809-2019]. Disponível em

http://www.ipea.gov.br/portal/images/stories/PDFs/relatorio_institucional/180604_atlas_da_violen cia_2018.pdf

FARIAS, Lindbergh (Relator) (2016), RELATÓRIO FINAL CPI Assassinato de jovens. Brasília: Senado Federal [Consult. 18-09-2019]. Disponível em https://www12.senado.leg.br/noticias/arquivos/2016/06/08/veja-a-integra-do-relatorio-da-cpi-doassassinato-de-jovens

FEFFERMANN, Marisa (2013), "A luta contra o genocídio da juventude negra: reflexões sobre a realidade brasileira", in XXIX Congreso Alas Chile-Crisis y Emergencias Sociales en América Latina, Anais 1807-0310 [Consult. 18-09-2019]. Disponível em https://docplayer.com.br/8993046A-luta-contra-o-genocidio-da-juventude-negra-reflexoes-sobre-a-realidade-brasileira.html

FIGUEIREDO, Ângela; GROSFOGUEL, Ramón (2009), "Racismo à brasileira ou racismo sem racista: colonialidade do poder e a negação do racismo no espaço universitário". Sociedade $e$ Cultura, Goiânia, v. 12, n. 02, pp. 223-234 [Consult. 18-09-2019]. Disponível em https://www.revistas.ufg.br/fchf/article/view/9096/6270

FLAUZINA, Ana L. P. (2013), “As dimensões raciais do processo de ratificação da Convenção do Genocídio nos Estados Unidos”. Universitas/Jus, v. 24, pp. 1-9 [Consult. 18-09-2019]. Disponível em https://www.publicacoesacademicas.uniceub.br/jus/article/view/2207/1887

GOMES, Nilma L. (2017), O movimento negro educador: saberes construídos nas lutas por emancipação. Petrópolis, Vozes.

GOMES, Nilma L.; LABORNE, Ana A. de P. (2018), "Pedagogia da crueldade: racismo e extermínio da juventude negra". Educ. rev., Belo Horizonte, v. 34, pp. 1-26 [Consult. 18-09-2019]. Disponível em http://www.scielo.br/pdf/edur/v34/1982-6621-edur-34-e197406.pdf 
GOMES, Rosangela (Relatora) (2015), Relatório Final Comissão Parlamentar de Inquérito Homicídios de Jovens Negros e Pobres. Brasília, Câmara dos Deputados [Consult. 18-09-2019]. Disponível em https://www.camara.leg.br/proposicoesWeb/prop_mostrarintegra?codteor=1362450

GUIMARÃES, Antônio S. A. (1999), Racismo e anti-racismo no Brasil. São Paulo: Fundação de Apoio à Universidade de São Paulo, Ed. 34.

HINTON, Alexander L. (2016), "Estudios críticos sobre genocídio". Revista de Estudios sobre Genocidio. Año 8, v. 11, Buenos Aires, pp. 13-26 [Consult. 18-09-2019]. Disponível em http://www.revistasuntref.com.ar/index.php/reg/article/view/2/1

MBEMBE, Achille (2018), Necropolítica: biopoder, soberania, estado de exceção, política de morte. Traduzido por Renata Santini. São Paulo, n-1 edições.

MELUCCI, Alberto (1989), “Um objetivo para os movimentos sociais?”. Lua Nova, n. 17, pp. 49-66 [Consult. 18-09-2019]. Disponível em http://www.scielo.br/pdf/ln/n17/a04n17.pdf

MONTEIRO, Antonio L. (1999), Crimes hediondos: texto, comentários e aspectos polêmicos. São Paulo, Editora Saraiva.

MORAIS, Rômulo Fonseca (2016), O extermínio da juventude popular no Brasil: uma análise sobre os "discursos que matam". Dissertação de Mestrado. PPGD, UFPA, Belém, 179p.

NASCIMENTO, Abdias (2016), O genocídio do negro brasileiro: processo de um racismo mascarado. São Paulo, Perspectiva.

NETO, Fernando L. (2018), "Os sentidos de participação na formação de coletivos", in $42^{\circ}$ Encontro Anual da ANPOCS, outubro 2018, Caxambu/MG [Consult. 18-09-2019]. Disponível https://anpocs.com/index.php/papers-40-encontro-3/gt-31/gt24-19/11318-os-sentidos-departicipacao-na-formacao-de-coletivos/file

PERISSINOTTO, Renato; SZWAKO, José (2017), "Movimentos sociais como teóricos políticos: Wolin, ideias e políticas públicas”. Lua Nova, v. 1, pp. 231-263 [Consult. 18-09-2019]. Disponível em http://www.scielo.br/pdf/ln/n102/1807-0175-ln-102-231.pdf

ROSENBERG, Sheri P. (2016), "El genocídio es un processo, no un acontecimiento". Revista de Estudios sobre Genocidio. Año 8, v. 11, pp. 27-36 [Consult. 18-09-2019]. Disponível em http://www.revistasuntref.com.ar/index.php/reg/article/view/4/2

SANTOS, Sales A. (2015), "A universidade brasileira é um dos instrumentos para produção da violência racial?". Educere et Educare, v. 10, pp. 653-669 [Consult. 18-09-2019]. Disponível em http://e-revista.unioeste.br/index.php/educereeteducare/article/view/12604/9018

SCHWARCZ, Lilia Moritz (1993), O espetáculo das raças: cientistas, instituições e questão racial no Brasil. São Paulo, Companhia das Letras.

SILVA, Franciane C. (2018), Corpos dilacerados: a violência em contos de escritoras africanas e afro-brasileiras. Tese (Doutorado em Letras). PPGL, PUC-MG, Belo Horizonte, 210 p.

WAISELFISZ, Julio J. (2016), Mapa da violência, homicídios por armas de fogo no Brasil. Brasília, Ministério da Justiça e Cidadania, Secretaria Especial de Políticas de Promoção da Igualdade Racial (SEPPIR), Flacso Brasil. 


\begin{abstract}
This article presents a reflection on the understanding of racial relations in Brazil and the violence imbricated in this process as a genocide of the black population. To do so, a reading of antiracist struggles, undertaken by black social movements, is made that denounces the existence of such extermination. The book "The Black Genocide of Brazil: The Process of Masked Racism" written by Abdias Nascimento and three social movements that specifically work against the genocide of black youth is particularly focused. The plot sewn throughout the text allows to understand that the understanding of the violence against the black population as a genocide has been a political strategy of the black movements, seen as provocateurs of annoyance.
\end{abstract}

Keywords: Genocide; racial violence; black movements; genocide of the black population.

\title{
Resumen
}

Este artículo tensa una reflexión sobre la comprensión de las relaciones raciales en Brasil y las violencias imbricadas en este proceso como un genocidio de la población negra. Para ello, se hace una lectura de luchas antirracistas, emprendidas por los movimientos sociales negros, que denuncian la existencia de tal exterminio. Se enfoca, en especial, el libro "El genocidio del negro brasileño: el proceso de un racismo enmascarado" escrito por Abdias Nascimento y tres movimientos sociales que actúan específicamente contra el genocidio de la juventud negra. La trama cosida a lo largo del texto permite aprehender que la comprensión de las violencias contra la población negra mientras un genocidio ha sido una estrategia política de los movimientos negros, vistos como provocadores de incomodidad.

Palabras clave: Genocidio; violencia racial; movimientos negros; genocidio de la población negra. 